Dossiê - Simpósio USP "Construindo diálogos interdisciplinares"

\title{
História da ciência e interdisciplinaridade: alguns exemplos ${ }^{1}$
}

\author{
Lia Queiroz do Amaral \\ Professora Titular do Instituto de Física da USP \\ amaral@if.usp.br
}

Recebido em 25/02/2018. Aprovado em 09/05/2018.

Como citar este artigo: Amaral, Lia Queiroz; "História da ciência e interdisciplinaridade: alguns exemplos". Khronos, Revista de História da Ciência, nº5, p. 89-111. 2018. Disponível em <http://revistas.usp.br/khronos>. Acesso em $\mathrm{dd} / \mathrm{mm} /$ aaaa.

Resumo: Um curso de Iniciação ao Pensamento Científico, estruturado e ministrado na Universidade Aberta à Terceira Idade da USP deu origem a esta visão de uma História da Ciência na perspectiva de seu desenvolvimento no Ocidente, com finalidade de Divulgação Científica para público leigo e também como texto didático. São apresentados tópicos que introduzem as bases conceituais e a interdisciplinaridade existente nas Ciências Exatas, focalizando a autoconsistência no conteúdo do conhecimento, utilizando narrativas históricas, sem excessos de formalismo acadêmico. São discutidas as diferenças entre Conhecimento e Ciência, a evolução dos conceitos de Mecânica e Astronomia, da antiguidade até Newton, e da Matemática até o século 17. Em seguida é discutida a união da Física com a Química, na virada do século 19 para o século 20, definindo as Ciências Exatas. Comentários sobre Metodologia Científica e Interdisciplinaridade nas Ciências da Natureza fecham o texto.

Palavras-chave: narrativa histórica, divulgação cientifica, autoconsistência, aprendizado ativo.

\section{History of science and interdisciplinarity: some examples}

\begin{abstract}
A course of Initiation to Scientific Thought, structured and taught at the University Open to the Third Age of USP gave rise to this vision of a History of Science in the perspective of its development in the West, with the purpose of Scientific Dissemination to lay public and also as didactic text. Topics that introduce the conceptual bases and the interdisciplinarity existing in the Exact Sciences are presented, focusing on self-consistency in the content of knowledge, using historical narratives, without excess of academic formalism. The differences between Knowledge and Science, the evolution of the concepts of Mechanics and Astronomy, from antiquity to Newton, and from Mathematics to the 17th century are discussed. Next, the union of Physics with Chemistry at the turn of the 19th century is discussed. century, defining the Exact Sciences. Comments on Scientific Methodology and Interdisciplinarity in the Natural
\end{abstract}

${ }^{1}$ Agências de fomento: projetos INCT (CNPq, MCT, FAPESP) e NAP_USP, ambos de Fluidos Complexos. 
Sciences close the text.

Keywords: historical narrative, scientific divulgation, self-consistency, active learning.

\section{Introdução}

A forma de transmissão do conhecimento passa atualmente por grandes transformações. A educação em Ciência torna-se mais inteligível quando focaliza a forma como o conhecimento foi obtido (História da Ciência), bem como a evolução das ideias e conceitos que marcam o avanço do conhecimento humano. Além disso, a linguagem utilizada na transmissão dos conteúdos também se altera, abandonando formatos usuais na academia, mas de pouca inteligibilidade para a sociedade. O conceito de Transposição Didática, teórico e com muitas limitações para sua aplicação na prática, está dando lugar a outras formas de transmissão de conhecimento. Em particular a Divulgação Científica, focalizada no conteúdo do conhecimento, e a narrativa histórica, sem excessos de formalismo acadêmico, se prestam mais à passagem de um ensino formal, centrado em aulas expositivas, ao conceito atual de aprendizado ativo.

A interdisciplinaridade apresenta problemas, pois cada disciplina se desenvolveu a partir de critérios próprios, não havendo em geral pontes conceituais e metodológicas entre elas, as condições de sínteses não são triviais. Focalizo uma experiência feita em Cursos oferecidos na Universidade Aberta à Terceira Idade da USP, com abordagem histórica e ênfase na autoconsistência interna do conteúdo científico, na interface física / química / biologia, ou seja, Ciências da Natureza. Foi estruturado um curso de "Iniciação ao Pensamento Científico" ministrado por três semestres consecutivos, a partir de março de 2005. O grupo de cerca de 20 alunos era formado por homens e mulheres com diferentes formações profissionais e experiências de vida, interessados em conhecer mais sobre Ciência. A interação com os alunos de terceira idade baseou-se sobretudo na curiosidade, que existe naturalmente nos seres humanos desde a mais tenra infância e que é responsável pelas descobertas, e também pela criatividade, tanto de crianças como de adultos. $\mathrm{O}$ autor liberou sua própria curiosidade, e criatividade, estimulando os alunos de terceira idade a fazerem o mesmo. O material dessa experiência não foi publicado, nem será usado neste artigo. Apenas alguns tópicos estão sendo retomados agora, após mais de uma década, dedicada a outras atividades de pesquisa, mais ortodoxas. As referências citadas nas notas levaram a pesquisas com critério próprio na internet, em particular na Wikipédia, que não são citadas quando correspondem a conhecimento de uso comum.

Neste artigo são elaborados, de forma livre, alguns assuntos que considero interessantes para divulgação científica, integrando narrativas históricas com conteúdo científico que traz novas abordagens às bases conceituais necessárias tanto para uma definição de Ciência, como para compreensão de sua evolução na cultura ocidental, focalizando alguns exemplos de interdisciplinaridade.

\section{Conhecimento X Ciência Moderna}

O tópico inicial do curso de Iniciação ao Pensamento Científico focalizou as diferenças entre Conhecimento e Ciência, que não estavam claras para os alunos do curso. Conhecimento, presente em todas as sociedades e culturas humanas, é construído a partir da memória de resultados obtidos por ensaio e erro, sendo de natureza local e subjetiva. De maneira geral tem propósitos sociais, visando soluções empíricas para problemas específicos. Máquinas simples, como alavancas, acompanham a história da humanidade, desde seu início, pois até os cabos dos machados de sílex, dos homens primitivos, baseavam-se em seu funcionamento. Esse tipo de conhecimento está presente em todas as culturas da antiguidade, como as existentes no Egito, na 
Mesopotâmia e na Índia, mas apresenta diferenças relacionadas, por exemplo, com o desenvolvimento da matemática em cálculos astronômicos. A geometria desenvolveu-se mais no Egito, a partir da necessidade de medidas de terras cujas fronteiras eram destruídas pelas inundações do rio Nilo. ${ }^{2} \mathrm{O}$ uso de metais, por volta de 4000 a.C. (antes de Cristo) leva a outro nível de experimentação baseada em ensaio e erro, e o início da escrita na idade do bronze marca a passagem da pré-história à história, permitindo a transmissão do conhecimento entre gerações, de forma menos pessoal.

De maneira geral, princípios de mecânica, materiais e o artesanato se inserem em "tecnologias", enquanto cosmologia e medicina se inserem em "mitologias e mágica". Mas papiros egípcios se aproximam de apresentação de resultados empíricos de métodos de cura e de casos sem esperança. A medicina avança por explorações feitas tanto em cadáveres como em seres vivos, tanto animais como humanos. Medicina e biologia seguem o princípio de comparação e sistematização na busca de uma classificação de seres vivos, tanto plantas como animais. A contribuição de Aristóteles (384-322 a.C.), de família de médicos, foi fundamental na sistematização em biologia macroscópica, mantendo-se até o século 18, quando o botânico, zoólogo e médico sueco Carolus Linnaeus publica em 1735 Systema Naturae (Sistema Natural), sintetizando o conhecimento da época, após o surgimento de observações em microscópio. Mas aqui seguiremos outra direção, buscando inicialmente a compreensão dos fenômenos naturais da matéria inanimada.

Por volta de 700 a.C. aplicações de matemática à astronomia permitem métodos preliminares de predição baseados em observações de longo alcance e a confecção de calendários. Cidades gregas começam a competir com monarquias vizinhas, no chamado "milagre grego, o nascimento da Filosofia". Na Ásia Menor, o grego Thales de Mileto faz a passagem de cosmogonias mitológicas para a filosofia natural, com ciência racional e secular, e Pitágoras no sul da Itália dá bases à matemática. Os filósofos pré-socráticos surgem no período 600 - 400 a.C., seguidos por Platão e Aristóteles no período 400 - 300 a.C, que fundaram respectivamente a Academia e o Liceo. O período helenístico da grande ciência grega, com Euclides e Arquimedes, vai de 300 a 100 a.C. Assim, desenvolve-se na Grécia a metodologia da razão, ou lógica, com o estudo de regras de pensamento, e princípios de dedução como inferência lógica a partir de premissas conhecidas, definindo a geometria de Euclides, que permanece até hoje. Mas o processo de indução é menos satisfatório, e também as relações entre teoria e experiência permanecem nebulosas.

Segue-se o período Greco-romano de 100 a.C. a 600 d.C. (depois de Cristo), quando se inicia novo enfoque espiritual, com o início do cristianismo. A herança grega passa então aos árabes e ao ocidente latino medieval.

$\mathrm{Na}$ antiguidade, máquinas simples como alavanca, polia e parafuso, foram estudadas por Arquimedes e é bem conhecida sua frase: "Deem-me uma alavanca e um ponto de apoio e moverei a Terra", com desenvolvimento da teoria do torque na rotação. A estática, fundamental para o equilíbrio das construções, já era bem conhecida na antiguidade, assim como a lei da alavanca, com proporcionalidade inversa entre os pesos e os braços da alavanca. Mas o mesmo não pode ser dito da cinemática e da dinâmica, englobadas junto com Estática em Mecânica.

O conceito de "ciência moderna" desenvolve-se nos séculos 16 e 17, a partir da renascença italiana, com a mecânica estruturada por Galileu, considerada "universal e objetiva". Afasta-se da Filosofia, baseando-se na matemática e em experimentos programados para testar teorias.

${ }^{2}$ Clagett, Marshall. Greeek Science in Antiquity. New York: Dover Publications, 2001. Republicação do original. New York: Abelard Schuman, 1955. 
Surge então uma questão fundamental, focalizada inicialmente neste artigo: quais razões podem explicar o fato de a Física ter demorado cerca de 2000 anos para se estruturar, e os princípios básicos do movimento permaneceram desconhecidos??

A resposta me parece clara: os gregos não deviam ter o conceito de "aceleração", ou seja, variação da velocidade com o tempo, necessário para a compreensão do movimento!

Para explicar em mais detalhes esse fato é necessário pesquisar o conhecimento sobre Mecânica na Idade Média. ${ }^{3}$

\section{A Revolução de Galileu na Mecânica Terrestre}

O primeiro ponto a enfatizar é que a contribuição essencial de Galileu foi na Mecânica do movimento na Terra, que define o início da Física.

Aristóteles usava duas definições para o mais rápido numa competição:

- o que atravessava espaços iguais em menos tempo

- o que atravessava maiores espaços no mesmo tempo

Ele considerava que a velocidade era diretamente proporcional à distância percorrida, $\mathrm{O}$ que é equivocado. Ou seja, não existia ainda o conceito de velocidade como espaço dividido por tempo! $\mathrm{Na}$ antiguidade medidas de tempo eram feitas somente em Astronomia, relativas aos períodos que definem as estações, os meses e os dias. Já existiam relógios de sol, e também de água, mas que serviam a outros propósitos, não ao estudo do movimento dos corpos na terra. Existiam medidas de comprimento, área e volume, e também de pesos, e moedas, com finalidades comerciais.

Após Aristóteles houve um filósofo grego, Strato de Lampsacus, diretor do Liceo em Atenas ( 300 a.C.) que, estudando a diferença entre quedas de gotas de água e água continua, chegou a propor que um corpo completa a parte final de sua trajetória em queda num tempo menor do que gasta na parte inicial, ou seja, uma primeira evidência de aceleração. Mas essas ideias não foram transmitidas nem para os árabes nem na tradição latina. Somente na Idade Média, no século 13, o matemático Jordano de Nemore (Giordano of Nemi) escreve sobre Mecânica e outros temas, descrevendo movimentos uniformes e acelerados.

Para fazer uma discussão sobre Física e Astronomia é necessário relembrar que a visão de Aristóteles sobre a natureza era de caráter qualitativo e não matemático, distinguindo como essencialmente diferentes as atividades celestiais das terrestres.

O problema básico da filosofia grega era a determinação da "physis", palavra grega que pode ser traduzida por "natureza enquanto fonte de progresso e evolução". A busca dos gregos pela physis do universo levou a três modos característicos de ver a natureza, que tiveram enorme influência no pensamento ocidental. A primeira é a visão física ou material, que enfatiza a realidade da matéria e do movimento, bem como a existência de espaço vazio. A visão física atribuía a substância do conhecimento aos sentidos, e atingiu sua expressão mais alta na teoria atômica de Democritus ( 500 a.C.), na qual átomos invisíveis e indivisíveis se associavam em diferentes

\footnotetext{
${ }^{3}$ Clagett, Marshall. Science of Mechanics in the Middle Ages. Madison: The University of Wisconsin Press, 1959.
} 
configurações. A segunda solução vai da visão psíquica, ou formal da natureza, até a visão matemática, enfatizando a realidade e permanência de formas, ideias e conceitos. Essa visão atingiu sua expressão sistemática com Platão.

A terceira visão da natureza, aquela de Aristóteles, caracteriza-se por um compromisso, rejeitando a ênfase colocada pelos materialistas na "matéria" e pelos platonistas na "forma". A visão de Aristóteles coloca matéria e forma como inseparáveis e inextrincavelmente ligadas. Dessa maneira conseguia explicar tanto a geração (vir a ser) como a corrupção (deixar de ser), necessárias ao tipo de organização que existe nos organismos vivos. Ele descreve "movimento" como a realização de algo que existe potencialmente. Os elementos na Terra são considerados como tendo "locais naturais", e se movimentam para retornar ao local natural, a terra no centro, a água em seguida, depois o ar e o fogo. Quando removemos um corpo de seu lugar natural, com um movimento violento, ele retornará por um movimento natural ao seu lugar natural. Essa lógica descreve o mundo terrestre, sublunar. Distinto deste, existe o mundo celestial, incluindo a Lua, o Sol, os planetas e as estrelas, formados por um quinto elemento, o éter, de natureza qualitativa eterna, com tendência apenas ao movimento circular, que não exige nem força nem resistência. Essa visão, nunca aceita pelos atomistas, persiste entre os filósofos naturais até a renascença, no século 16. Mas vale ressaltar que as tentativas mecanicistas imaginadas pelos materialistas gregos para explicar o cosmos não prosperaram.

Voltando à Mecânica, no século 14 desenvolve-se em Oxford um avanço no estudo do movimento com velocidade variável, com o teorema da velocidade média deduzido no Merton College em $\sim 1330$. Mas o conceito de velocidade instantânea ainda não existia!

É nesse contexto que se insere o trabalho de Galileu Galilei (1564 - 1642), ${ }^{4}$ que nasceu em Pisa, mas a família mudou-se depois para Florença. Seu pai, Vincenzo Galilei, era um músico independente, teórico e prático, muito influente na sua época, ${ }^{5}$ como será detalhado depois. Galileu tinha muitos talentos e estudou inicialmente medicina em Pisa, conforme desejo de seu pai, e depois se interessou por matemática, onde vislumbrou a possibilidade de uma profissão lucrativa, ao entrar em contato com o matemático e engenheiro militar do grão-duque da Toscana, cuja corte passava férias em Pisa. Nas universidades medievais a educação era abrangente, sem fronteiras definidas entre as matérias, e medicina incluía filosofia natural, lógica e matemática, e também astronomia, pois médicos elaboravam horóscopos de seus pacientes. Galileu familiarizou-se então com álgebra e geometria, redescobrindo Euclides e Arquimedes.

Em Pisa Galileu estudou o movimento do pêndulo, determinando que o seu período não depende da massa, mas apenas do comprimento do fio. Foi o primeiro a pensar que este fenômeno permitiria fazer relógios muito mais precisos, e já no final da sua vida viria a trabalhar no mecanismo de escape que mais tarde originaria o relógio de pêndulo. Sem se formar, voltou a Florença, onde viveu dando aulas particulares. Foi nessa época que inventou a balança hidrostática, cujo mecanismo descreveu no breve tratado "La bilancetta", publicado postumamente em 1644. Fez também uma viagem a Roma, onde entrou em contato com matemáticos jesuítas do Colégio Romano, com quem discutiu suas teorias para calcular o centro de gravidade de vários objetos reais.

Nessa época a Europa enfrentava a Reforma protestante no norte da Europa, e a ContraReforma católica, com a criação da ordem dos Jesuítas e a reorganização da Inquisição romana. Ao mesmo tempo morre o grão-duque Francisco de Médici, em Florença, sucedido por seu irmão Fernando, cardeal e irmão do matemático Guidobaldo, que Galileu conheceu em Roma. Dessa forma, devido a suas relações com o poder em Florença, Galileu em 1589 foi nomeado

\footnotetext{
${ }^{4}$ Naess, Atle. Galileu Galilei, Um revolucionário e seu tempo. Rio de Janeiro: Zahar, 2015. Tradução George Schlesinger da versão inglesa, Berlin: Springer, 2005. Original norueguês, Gyldendal Norsk Forlag, 2001.

${ }^{5}$ Bromberg, Carla. Vincenzo Galilei contra o numero sonoro. São Paulo: Editora da PUC, Livraria da Física Editorial, FAPESP, 2011.
} 
para a cátedra de matemática na Universidade de Pisa, onde realizou as suas famosas experiências de queda de corpos. Nestas, demonstra que a velocidade de queda não depende do peso, mas percebeu também que a velocidade estava relacionada com o meio através do qual o corpo caia, sendo diferente no ar e na água. Demonstrou os erros de Aristóteles, que sustentava que qualquer objeto em queda livre atingiria uma velocidade fixa, proporcional ao peso do objeto. Galileu tinha Arquimedes como modelo, e inicialmente concluiu equivocadamente que a velocidade de queda de um corpo seria proporcional à sua densidade de massa. Nessa época Galileu ainda não tinha condições de perceber o âmago da questão do movimento: a necessidade de abstrair totalmente o atrito, para chegar em leis universais válidas na ausência de atrito!

Após a morte do pai em 1591, Galileu, pressionado por questões financeiras para o sustento da família (mãe e 3 irmãos menores), consegue através de contatos influentes uma posição em Pádua, dentro da república de Veneza, tão importante quanto Florença. Nessa época Giordano Bruno fora preso em Veneza, e executado pela inquisição em Roma, e a força das ideias de Nicolau Copérnico, cônego matemático polonês, morto 50 anos antes, começava a se fazer sentir seriamente. Em Pádua Galileu une-se a uma moça de Veneza, tem filhos, desenvolve e comercializa um compasso geométrico e militar, faz experimentos com planos inclinados, mas começa também seu envolvimento com a Astronomia.

Somente no final de sua vida, em prisão domiciliar, teve tempo de redigir seu livro básico sobre mecânica, que foi seu último livro, "Discursos e demonstrações matemáticas acerca de duas novas ciências a respeito da mecânica e dos movimentos locais" (1638). Galileu descreve um experimento com plano inclinado em favor de suas teses sobre a queda dos corpos, o experimento é descrito por uma esfera de bronze que desce sobre uma canaleta em uma viga de madeira inclinada, enquanto uma quantidade de água cai de um recipiente, para marcar o tempo, sua descrição impressiona por sua semelhança com a concepção atual de experimento. Antes da consideração do movimento acelerado e do movimento natural de queda, Galileu examina o movimento uniforme, no qual para todos os tempos iguais um objeto percorre espaços iguais, e sugere o movimento uniformemente acelerado como aquele no qual em quaisquer tempos iguais há incrementos iguais na velocidade. Suas descobertas sobre o movimento tiveram significado especial pela abordagem matemática usada para analisá-las, com avanço na cinemática. A contribuição de Galileu foi essencial para o nascimento da Física moderna, e essas experiências de Galileu constituem a base do curso de Física no primeiro ano das Universidades até os dias de hoje. A variação do ângulo do plano inclinado permite a compreensão tanto do princípio de inércia do movimento na direção horizontal, com abstração do atrito, como o movimento na direção vertical, com aceleração constante devida à gravitação. Galileu definiu também a questão da relatividade entre sistemas inerciais: o movimento depende do observador, mas não existe diferença observável entre referenciais inerciais, que se movem com velocidades relativas constantes. Este princípio básico de Galileu só foi ampliado por Einstein no século 20.

\section{Astronomia: da Antiguidade a Copérnico}

Antes de deixar Florença e ir para Pisa, Galileu deu uma palestra na Academia, sobre a localização e as dimensões do inferno de Dante, sendo profundo conhecedor da Divina comédia. A plateia sabia que a terra era redonda, com circunferência calculada por Eratóstenes de Alexandria (276 - 194 a.C), a partir da medida da posição do Sol (medida em ângulos) num determinado dia em Siena e em Alexandria, separadas por $800 \mathrm{~km}$. Por trigonometria simples chegou num diâmetro para a terra que difere só cerca de $2 \%$ do valor conhecido hoje.

Na questão da relação entre a Terra e o resto do universo, Galileu aceitou a modelo de Ptolomeu, que colocava a Terra no centro do universo, em torno da qual giram os corpos celestiais, em orbitas circulares, presos a esferas invisíveis, numa interação muito complexa entre teologia e astronomia. Nessa época Galileu já conhecia a teoria de Copérnico, mas não disse nada 
sobre isso, porque estava claro para ele que a estrutura cosmológica e teológica do modelo ptolomaico não seria abandonada sem resistência.

Desde a mais remota antiguidade a preocupação com o movimento do Sol, da Lua, dos planetas e das estrelas esteve vinculada ao cotidiano humano, em função tanto das mudanças dia / noite como das mudanças das estações, que definem o ambiente que nos circunda. Todos os povos desenvolveram cosmologias conectando esses eventos a alguma forma de religião e também a formas de tratar as doenças do corpo, e vislumbrar acontecimentos futuros.

Para poder situar como se colocavam as teorias sobre Astronomia vigentes na época de Galileu, é conveniente focalizar um livro em particular: o Commentariolus, pequeno comentário de Nicolau Copérnico sobre suas próprias hipóteses acerca dos movimentos celestes, mas na tradução para o português feita por Roberto de Andrade Martins, incluindo uma Introdução crítica e Notas detalhadas, que enriquecem muito a obra, tornando-a essencial. ${ }^{6}$ Além da tradução, dá uma perspectiva bastante completa da astronomia antes de Copérnico e um apanhado das pesquisas históricas sobre o tema.

É conveniente também ler sobre a História da Astronomia, por exemplo no material didático produzido pela Universidade Federal do ABC. ${ }^{7}$

Ressalto os pontos mais importantes para compreensão do assunto:

1) A astronomia desenvolvida pelos gregos tinha aspectos místicos e matemáticos, concebidos pelos filósofos pré-socráticos, e aceitos por Platão e Aristóteles, unindo as observações do céu, como visto da Terra, com movimentos circulares, periódicos e harmônicos, esteticamente associados à divindade que habitava o Céu. Matematicamente qualquer movimento periódico pode ser descrito pela superposição de movimentos circulares. A observação visual do céu permite verificar a existência de movimentos periódicos ao longo do dia, semana, e anos, com os corpos celestes movendo-se em torno da Terra, do nascente para o poente, em círculos paralelos. Essas observações levam naturalmente à noção de que a Terra está no centro, e parada pois não sentimos a existência de nenhum movimento da terra. Os corpos celestes parecem estar numa superfície esférica que envolve a terra, a uma distância da ordem da distância aos planetas, e esse foi o modelo adotado pela Astronomia na antiguidade. A distância de um astro em relação à Terra pode ser estimada pela paralaxe (deslocamento aparente de um objeto quando se muda o ponto de observação) conforme o astro é visto em pontos diferentes da Terra. A ausência de paralaxe na observação das estrelas apoiava na antiguidade a ideia de uma esfera fixa das estrelas. O Sol atravessa as constelações ao longo do ano, marcando os eventos estudados na Astrologia, então indistinguível da Astronomia. Os planetas apresentam um movimento dito retrógrado em relação às estrelas fixas quando observados ao longo do tempo, com paradas e recuos numa trajetória aparente, também periódica.

2) Aristarco de Samos (310 — 230 a.C.) foi o primeiro astrônomo a realmente acreditar em um modelo heliocêntrico (o Sol no centro) para o cosmos, supondo que o movimento diário das estrelas era devido à rotação da Terra. Além disso, criou métodos bastante engenhosos para estimar as distâncias e os tamanhos relativos do Sol, da Lua e da Terra. Aristarco calculou que o Sol está, aproximadamente, 20 vezes mais afastado de nós do que a Lua. E que o Sol é cerca de 20 vezes maior do que a Lua e 10 vezes maior do que a Terra. Analisando a velocidade de deslocamento do sol ao longo do ano concluiu que o centro de rotação não estava na terra, como

${ }^{6}$ Copernico, Nicolau. Commentariolus, pequeno comentário de Nicolau Copérnico sobre suas próprias hipóteses acerca dos movimentos celestes. Introdução, Tradução e Notas de Roberto de Andrade Martins. $2^{\mathrm{a}}$ edição. São Paulo: Editora Livraria da Física, 2003.

${ }^{7}$ https://astronomiaufabc.files.wordpress.com/2016/06/download-pdf1.pdf

Acessada em 15/01/2018, e outros textos de astronomia da UFABC. 
primeiro astrônomo a considerar uma orbita excêntrica em um sistema orbital. Mas não desenvolveu um sistema completo de cálculos, como elaborado depois por Ptolomeu.

3) Claudius Ptolomeu (90 - 168 d.C.), um dos grandes filósofos da Escola de Alexandria, fez um sistema geométrico-numérico para descrever os movimentos do céu, de acordo com as tabelas de observações babilônicas. O Almagesto colocava a Terra como um ponto fixo no centro do cosmos. Era muito sofisticado e dava predições corretas, unindo a geometria grega com noções de cálculo aritmético dos babilônios, incorporadas na trigonometria grega. O conjunto de 13 livros incluía elementos de astronomia esférica, teorias solar, lunar e planetária, além de falar de eclipses e das estrelas fixas. Existia o sentido instrumentalista de descrever os fenômenos observados, sem implicação de realismo quanto a descobrir a verdade da natureza. O Almagesto permaneceu por aproximadamente 1500 anos como o texto definitivo sobre astronomia.

4) Nicolau Copérnico [1473-1543], astrônomo e matemático polonês, cônego da igreja católica, desenvolveu a teoria que colocou o Sol no centro do cosmos. O Commentariolus de Copérnico, manuscrito não publicado anterior a sua obra maior, de Revolutionibus Orbium Caelestium, contém as ideias essenciais, mas não desenvolve demonstrações matemáticas. Em particular o número de círculos usados não é o mesmo, foram depois aumentados de 34 para 48, e permanece o axioma de órbitas como circunferências. A contribuição de Copérnico foi colocar a Terra em movimento em torno do Sol e elaborar uma teoria matemática detalhada, que pudesse explicar as observações, assim como o modelo de Ptolomeu fazia. Mas também tentava descrever a realidade física, embora não fosse possível nenhuma comprovação. Copérnico faz uma crítica a Ptolomeu no que diz respeito à distância entre a Terra e a Lua, que tem grandes variações ao longo das trajetórias no modelo de Ptolomeu, e variações pequenas, em acordo com a observação, no modelo de Copérnico, que também permite comparar diferenças entre os planetas.

5) É necessário o conhecimento da teoria matemática de Ptolomeu (inacessível a leigos) e também o que era conhecido pelas observações astronômicas existentes na antiguidade, para ser possível entender a dimensão do problema. Na época de Galileu as duas descrições eram de fato idênticas: afirmar que o Sol gira em torno da Terra, que está parada, ou que a Terra gira em torno de seu eixo e do Sol leva a teorias matemáticas muito complexas, ambas capazes de explicar as observações existentes. Ambas exigem postular um grande número de círculos para descrever os movimentos relativos envolvendo vários planetas.

Aristóteles deu argumentos reais contra a rotação da Terra: se a Terra girasse um objeto atirado verticalmente para cima deveria cair num lugar diferente ao do lançamento, pois a terra se moveria enquanto ele estivesse no ar, mas cai no mesmo lugar. Ptolomeu argumentou que se a Terra girasse os corpos deveriam ser atirados para fora dela, e também que deveria ser mais difícil atirar uma flecha para leste do que para oeste. Portanto toda nossa experiência na Terra vai realmente na direção de uma Terra parada e no centro do universo! Copérnico não resolveu essas questões, mas começou a alterar a visão cosmológica, pois seu modelo exigiu que as estrelas estivessem muito mais distantes do que se pensava, o que significa a existência de um vazio imenso.

O ponto importante a ressaltar é que as observações eram todas feitas no referencial da Terra, e que podiam ser muito bem explicadas pelo sistema de Ptolomeu. O sistema de Copérnico não conseguia de fato mudar a correlação entre teoria e observações. Mas tanto Copérnico, como Galileu, eram realistas, atribuindo sentido físico a suas teorias.

Galileu tinha conhecimento dos resultados astronômicos tanto de Ptolomeu como de Copérnico e também das inferências teológicas e religiosas, que uniam o Céu aristotélico aos conceitos da Igreja e aos textos das Sagradas Escrituras. A contribuição de Galileu à Astronomia foi experimental, não teórica, mas ele assumiu uma militância filosófica e política que foram marcantes. 


\section{Astronomia e Física: Brahe, Kepler, Galileu e Newton}

Uma questão importante no questionamento das ideias de Aristóteles refere-se à descoberta de novas estrelas no céu, evidência clara do céu não ser imutável.

Três anos após a morte de Copérnico nasceu, numa família nobre dinamarquesa, Tycho Brahe (1546-1601), o último grande astrônomo observacional antes da invenção do telescópio. Com 26 anos observou uma estrela brilhante na constelação de Cassiopeia, a "nova de Tycho", e verificou que o seu brilho diminuiu nos meses seguintes, e depois descobriu um cometa. Frederick II da Dinamarca cedeu a Tycho Brahe a ilha Hven, entre Copenhagen e a Suécia, onde ele construiu o observatório de Uraniborg, com fundações sólidas que dessem estabilidade às medidas. Usando instrumentos de alta precisão, que ele mesmo fabricava, Tycho produziu entre 1576 e 1598, as maiores tabelas de dados astronômicos existentes até então. Verificando que estavam em desacordo com o modelo de Ptolomeu, mas não detectando qualquer evidência de movimento da Terra ao redor do Sol, propôs seu próprio modelo, uma modificação geocêntrica do modelo de Copérnico: o Sol e a Lua estavam em órbita em torno da Terra, mas os planetas restantes estavam em orbita em torno do Sol. Após a morte de Frederico da Dinamarca, Tycho viajou pela Europa e conseguiu do imperador Rodolfo II da Germânia a posição de astrônomo em Praga, e em 1600 Tycho contratou para ajudá-lo na análise dos seus dados um jovem e hábil matemático alemão chamado Johannes Kepler.

Johannes Kepler (1571-1630) era um teórico místico e sua obra serviu de base para a teoria da gravitação universal de Newton. Uma boa fonte sobre os aspectos místicos de seu trabalho é encontrada na Wikipédia, aqui dou apenas um breve resumo. Teve uma infância difícil, numa família alemã protestante, estudou teologia, mas desenvolveu já na infância amor pela astronomia, e tinha muito talento para matemática. Aprendeu as teorias de Ptolomeu e de Copérnico e defendeu o heliocentrismo de uma perspectiva tanto teórica quanto teológica. Kepler incorporou raciocínios e argumentos religiosos em seu trabalho, motivado pela convicção religiosa de que Deus havia criado o mundo de acordo com um plano inteligível, acessível através da luz natural da razão. Em 1594 conseguiu um posto de professor de matemática e astronomia em uma escola secundária em Graz, na Áustria. Lá publicou aos 25 anos sua grande obra, "O mistério cosmográfico", que admitia que os planetas (inclusive a Terra) giravam em torno do Sol, mas mostrou, com suposições, que nos espaços entre as órbitas dos planetas então conhecidos encontravam-se os cinco corpos perfeitos, poliedros regulares de Platão. Declarou que, por meio de seus esforços, o engenhoso plano de Deus era demonstrado pelo sistema de Copérnico.

Por ser protestante, Kepler foi obrigado a se exilar depois em Praga, trabalhando com Tycho Brahe, com quem não teve bom entendimento pessoal. Mas Tycho morreu menos de 2 anos depois, e Kepler herdou seu posto e conseguiu acesso a seus dados, aos quais se dedicou pelos 20 anos seguintes.

O planeta Marte tinha as observações mais precisas, e Kepler conseguiu explicar o movimento aparente de Marte aceitando o Sol parado, mas acrescentando uma ruptura radical quanto à forma da órbita, chegando em elipses, com o Sol num dos focos. As duas leis de Kepler foram publicadas no livro "A nova Astronomia”, em 1609, mas seus cálculos não tiveram muita repercussão na época:

- Lei das órbitas elípticas: A órbita de cada planeta é uma elipse, com o Sol em um dos focos. Como consequência da órbita ser elíptica, a distância do Sol ao planeta varia ao longo de sua órbita.

- Lei das áreas: A reta unindo o planeta ao Sol varre áreas iguais em tempos iguais. O significado físico desta lei é que a velocidade orbital não é uniforme, mas varia de forma regular: quanto mais distante o planeta está do Sol, mais devagar ele se move, ou seja, a velocidade areal é constante. 
Muito interessante na vida e trabalho de Galileu foi sua relação com Johannes Kepler, sete anos mais novo, que ele nunca conheceu pessoalmente, e com quem raras vezes se correspondeu. Em outubro de 1604 uma estrela nova foi vista por toda a Europa, e o astrônomo Kepler foi o primeiro a vê-la e escreveu um livro sobre ela, com preocupações astrológicas e também filosóficas e religiosas. Kepler e Galileu concluíram de forma independente que a nova estrela estava muito distante, em desacordo com a visão de Aristóteles.

Galileu foi informado em 1609 que um holandês havia inventado recentemente um aparelho que fazia objetos distantes ficarem mais próximos. A partir do compasso que havia construído, e do conhecimento de lentes dos artesãos de vidro de Veneza, Galileu construiu um telescópio e começou a estudar os céus. Com sua habilidade prática aperfeiçoou a lente e o tubo chegando num modelo com maior capacidade de ampliação. Focalizando a Lua, verificou que a superfície era irregular, sem a perfeição aristotélica. Descobriu depois as luas de Júpiter, que receberam o nome de estrelas mediceias em homenagem ao grão duque de Florença, editando o livro "A mensagem das estrelas". Galileu descobriu novas estrelas na Via Láctea, as fases de Vênus, e também observou as manchas solares. Com esses sucessos obteve reconhecimento público e a almejada posição em Florença, despedindo-se de Pádua e do Senado de Veneza, que havia lhe dado um cargo vitalício.

Galileu enviou a Kepler "A mensagem das estrelas", e Kepler respondeu com um trabalho apoiando Galileu, que não respondeu. Numa segunda carta Kepler diz que Galileu precisava obter mais resultados, diante de críticas existentes. Galileu respondeu, evitando porém a promessa de enviar um de seus telescópios a Kepler, e nunca utilizou os resultados de Kepler. Os escritos de Galileu têm o estilo científico moderno, muito diferente do misticismo de Kepler. As diferenças de personalidade entre ambos estão bem descritas em livro recente, ${ }^{8}$ que aborda em profundidade o envolvimento de Galileu com as manobras do poder político e suas dificuldades financeiras. Galileu queria abrir espaço e status para uma ciência não aristotélica, e sabia que isso estava vinculado à sua posição dentro da sociedade, junto ao poder político, não à aprovação dentro das torres de marfim da Academia.

Quando o rei da Boemia morreu, Kepler teve dificuldades com o poder, e deixou Praga estabelecendo-se em Linz. Quando sua mãe foi julgada como bruxa, entrou numa batalha legal e teológica para salvá-la. Sua obra seguinte, Harmonia do Mundo (1619) tinha especulações místicas, mas também continha sua terceira lei: o quadrado do período do planeta é proporcional ao cubo do maior raio de sua órbita. Acreditava ter encontrado a prova de seu misticismo planetário, a harmonia divina que deve permear o mundo. Kepler fez também trabalho em ótica, melhorando o telescópio e confirmou descobertas de Galileu, além de trabalhos em outros campos do conhecimento. Kepler viveu numa época em que não havia nenhuma distinção clara entre astronomia e astrologia, mas havia uma forte divisão entre a astronomia (um ramo da matemática dentro das artes liberais) e a física (um ramo da filosofia natural).

Convém ressaltar que foi o místico Kepler quem comprovou o sistema de Copérnico, e não Galileu, orgulhoso expoente da tradição toscana de pensamento cético e independente, que foi um racionalista moderno, mas com muita capacidade prática, e de observação da realidade.

As descobertas seguintes de Galileu, já de volta a Florença, o levaram depois a Roma. Seus movimentos políticos envolvendo articulações com os poderosos, a Igreja, vários papas, os jesuítas, a academia dos linces, o papa Urbano VIII, que era seu amigo pessoal, podem ser seguidos em detalhe na literatura. Sua obra mais politizada, o famoso "Diálogo sobre os dois principais

${ }^{8}$ Naess, 2005, op. cit. 
sistemas do mundo", publicado em 1632, corresponde a uma intensa campanha a favor do heliocentrismo e da liberdade de pensamento, dirigida à cultura organizada de sua época.

O lado político e polêmico de Galileu é bastante conhecido e explorado pelo público leigo, mas seu real valor científico só pode ser avaliado por físicos e astrônomos. As objeções contra o movimento da Terra não puderam ser todas respondidas por ele. Conseguiu rebater Aristóteles ao mostrar que um objeto lançado verticalmente cai de volta no mesmo lugar, considerando dois referenciais inerciais. Seu real alvo de crítica era a escolástica vigente no ensino medieval, cujo maior exemplo é a obra-prima de Tomás de Aquino, Summa Theologica, que visava conciliar o cristianismo com um sistema de pensamento racional da filosofia grega. Mas não conseguiu rebater Ptolomeu quanto aos efeitos de rotação da Terra, errou em particular na sua teoria das marés, a que deu grande ênfase nos Diálogos, e estava errada. Mas numa carta que escreveu no fim da vida, em suas últimas observações sobre a Lua, ele se pergunta sobre seu efeito nas marés e conclui 9: “... [as marés] que por consenso comum de todos, a lua é árbitro e superintendente”. Parece que no final de sua vida foi capaz da maior façanha intelectual: reconhecer seu erro a partir de um raciocínio crítico próprio.

O esforço inaudito e individual dos gigantes Brahe, Kepler e Galileu só atinge sua completude com Newton, que conseguiu dar as respostas que faltavam para compreensão do movimento, tanto na Terra como nos céus. A terceira lei de Kepler estabelece que planetas com órbitas maiores se movem mais lentamente em torno do Sol, Newton percebeu que isso implica na força entre o Sol e o planeta decrescer com a distância ao Sol.

Isaac Newton, nasceu na Inglaterra em 25/12/1642 pelo calendário Juliano (janeiro de 1643 pelo calendário atual), um ano depois da morte de Galileu. Seu pai morreu 3 meses antes de ele nascer, e sua mãe passou a administrar a fazenda da família. Quando sua mãe se casou com um pastor, Newton, com 3 anos, já de temperamento difícil e introspectivo, foi viver com sua avó. Aos 17 anos sua mãe tentou fazer dele um agricultor, mas ele conseguiu retornar ao King's College, adquirindo conhecimentos de matemática antes de ir estudar no Trinity College de Cambridge. Consta que o interesse de Newton por matemática começou aos 20 anos, quando ele comprou um livro de astrologia e não conseguiu entender a matemática usada nele, nem entendeu trigonometria, e resolveu estudar lendo os Elementos de Geometria de Euclides, aprendendo muito como autodidata. Por causa da peste negra, o Trinity College foi fechado em 1666 e Newton foi para a casa de sua mãe no campo, e nesse ano fez quatro trabalhos essenciais: binômio de Newton, cálculo infinitesimal, lei da gravitação universal e construiu um telescópio, observando a decomposição da luz solar num prisma.

Existem muitas evidências quanto à veracidade de Newton ter pensado na força da gravidade ao ver uma maçã cair de uma arvore, no jardim. Pensou que a mesma força poderia ser exercida pela Terra sobre a Lua, e talvez mantê-la em sua órbita. Num cálculo simples fez uma regra de três entre o movimento da maçã e o da Lua, imaginando a força gravitacional como a força centrípeta do movimento rotacional da Lua. Obteve a ordem de grandeza correta, admitindo que a massa da Terra estivesse concentrada no seu centro. Para provar que isso era de fato verdade, inventou o cálculo infinitesimal, e levou mais de uma década trabalhando para publicar seus resultados.

Tornou-se professor de matemática em Cambridge em 1669 e foi eleito Membro da Royal Society em 1672. Sua principal obra foi a publicação "Princípios Matemáticos da Filosofia Natural” em 1687, generalizando e ampliando as constatações de Kepler e de Galileu. Resumiu suas descobertas em três volumes, tratando o cálculo infinitesimal, astronomia, mecânica e física

\footnotetext{
${ }^{9}$ Idem, p. 220.
} 
em geral (leis dos movimentos, movimentos de corpos em meios resistentes, vibrações isotérmicas, velocidade do som, densidade do ar, queda dos corpos na atmosfera, pressão atmosférica, etc.). No terceiro volume enuncia a lei da gravitação universal, sendo o primeiro a demonstrar que os movimentos de objetos, tanto na Terra como dos corpos celestes, são governados pelo mesmo conjunto de leis naturais. Também trabalhou em Ótica e desenvolveu a teoria das cores.

As três leis de Newton são bem conhecidas, mesmo no ensino médio:

$1^{\text {a }}$ lei: Todo corpo continua em seu estado de repouso ou de movimento uniforme em uma linha reta, a menos que seja forçado a mudar aquele estado por forças imprimidas sobre ele. É também conhecida como princípio da inércia, uma extensão do princípio de inércia de Galileu.

$2^{a}$ lei: A mudança de movimento é proporcional à força motora imprimida, e é produzida na direção da linha reta na qual aquela força é imprimida (princípio da dinâmica). Definiu mudança de movimento como variação do produto da massa pela velocidade, que hoje em dia é reconhecida como mais correto do que usar aceleração, que só foi definida como derivada da velocidade mais tarde.

$3^{a}$ lei: A toda ação há sempre oposta uma reação igual, ou, as ações mútuas de dois corpos um sobre o outro são sempre iguais e dirigidas a partes opostas (princípio da ação e reação).

A lei da gravitação universal diz que a força sentida num corpo $\mathrm{M}_{1}$ devido à presença de outro corpo $\mathrm{M}_{2}$ é igual ao produto de uma constante de gravitação universal $\mathrm{G}$ pelo produto das suas massas $\left(M_{1} \times M_{2}\right)$, dividido pela distância entre eles ao quadrado, e que essa força atua na direção que une os 2 corpos. Note que essa lei recai na lei de queda dos corpos de Galileu quando um dos corpos é a Terra.

Newton aperfeiçoou as teorias que existiam antes dele e criou o sistema científico moderno, que junta observação, experiência, filosofia natural e matemática, e tornou-se presidente da Royal Society em 1703. Teve também participação política como membro do Parlamento Britânico, e em cargos burocráticos na casa da moeda britânica.

Mas é necessário ressaltar que Newton também foi alquimista, dedicando muitos de seus esforços aos estudos da alquimia, escrevendo muito sobre esse tema. Possuía uma extensa biblioteca de teologia e filosofia, e também foi teólogo, escrevendo obras teológicas.

Os detalhes sobre avanços na Física Clássica após Newton não serão revistos aqui, existem em muitos outros lugares. A questão do racionalismo versus o empirismo não é capaz de explicar a revolução na passagem do sistema geocêntrico para heliocêntrico, nem o avanço do conhecimento. Trata-se mais de um embate entre indução e invenção, uma centelha de intuição que permite a mudança de posição entre observador e observado, com implicações filosóficas profundas: a capacidade de "sair de si" e observar FATOS do mundo exterior.

\section{Matemática e Interdisciplinaridade}

A importância da Matemática na Astronomia e na Física ficou clara nos itens anteriores. Convém agora entrar na História da Matemática, conforme visto num livro muito bom para uma visão geral desse assunto. ${ }^{10}$ Como este é um texto de Divulgação, que deve ser compreensível a leigos, são focalizados conceitos de interesse geral.

\footnotetext{
${ }^{10}$ Burton, David M. The History of Mathematics. An introduction. Seventh edition. New York: Mc Graw Hill, 2011.
} 
A matemática engloba assuntos de natureza quantitativa e espacial, ou seja, números, tamanho, ordem e forma, que existem desde o início das culturas humanas, devido ao desejo / necessidade dos seres humanos de compreender e dominar o mundo natural à sua volta. É usualmente aceito que a matemática teve origem com problemas práticos de contar e gravar números, com símbolos, numa evolução lenta que não é possível conhecer com precisão. Algumas tribos da Austrália só conhecem a distinção entre um e dois, e tribos primitivas da America do Sul na região do Amazonas podem não ter sequer o conceito de número. Em outras tribos não existem palavras para números acima de um, mesmo sabendo contar até 6 , designam 3 por "doisum", quatro por "dois-dois", etc. A técnica mais antiga e imediata de contar é comparando o que deve ser contado com uma coleção de objetos conhecidos, como dedos, conchas ou pequenas pedras. Assim animais podem ser colocados em fila à noite, antes de serem soltos, e colocada 1 pedra para cada um, o conjunto de pedras representa o conjunto de animais, que será recontado no dia seguinte. Este é o primeiro passo no longo caminho de separar a sequência de números abstratos dos objetos a serem contados, e a forma de gravar números está ligada à comunicação escrita.

No império Inca do Peru, existia um complexo sistema de contagem, os "quipos", cordões com nós para registro de acontecimentos, sendo que nunca foi desenvolvido um sistema de escrita. A Grécia usava um sistema para representar números, utilizando letras do alfabeto grego, e os egípcios tinham uma representação de números nos hieróglifos.

Artefatos de ossos com marcas indicam que povos da idade da pedra, 30.000 a.C. já tinham sistemas de contagem por grupos, inclusive para contagem de tempo em dias das fases sucessivas da Lua. Achados arqueológicos comprovam a existência desse tipo de contagem tanto na Europa como no Oriente próximo. Contagens desse tipo existem até o presente em cidades pequenas da Europa, e também na Inglaterra. Lembremos que em inglês até hoje são usadas medidas antropomórficas e não decimais, introduzidas na Europa na época da Revolução Francesa.

O ponto a ressaltar aqui é que existe uma "matemática para coisas práticas", que existe desde o início mais remoto de todo agrupamento humano, e uma matemática rigorosa, grecohelênica, refinada pela introdução do raciocínio dedutivo e do rigor em provas. Os gregos faziam uma separação clara entre esses dois tipos de matemática, que na verdade coexistem. A descoberta dos números irracionais, já presentes no teorema de Pitágoras relacionando a hipotenusa com os lados de triângulos retângulos, afasta a matemática grega da aritmética simples, incluindo representações geométricas. Mas dentro da lógica grega era inconcebível uma divisão entre quantidades de categorias diferentes, e nunca chegaram numa definição exata de velocidade.

A própria matemática rigorosa desenvolve-se a partir de axiomas, postulados e hipóteses iniciais, que são o fundamento de uma demonstração, porém eles mesmos considerados 'evidentes \& indemonstráveis'. É importante entender que a matemática por si só não pode explicar a realidade, essa conexão é feita pelos conceitos, ideias formadas na mente humana e formuladas numa linguagem simbólica. ${ }^{11}$ Assim, espaço e tempo são conceitos que foram sendo construídos ao longo da evolução humana. A geometria euclidiana, que existe há mais de 2000 anos, deu formalização matemática ao conceito de espaço, que só foi alterado com o advento do conceito de espaço-tempo, surgido já no século 20, a partir de geometrias não euclidianas (ou curvas), elaboradas no século 19. Essas novas geometrias alteraram uma das hipóteses da geometria euclidiana, permitindo aberturas em novas direções.

\footnotetext{
${ }^{11}$ Queiroz do Amaral, Lia. Liberdade de expressão na produção científica, pp 116 - 130. In e-book Comunicação e liberdade de expressão: atualidades, Costa, Cristina (org.), São Paulo: ECA-USP, 2016.
} 
Assim dos tempos antigos até agora, a eclosão da criatividade matemática foi frequentemente seguida por séculos de estagnação. O interesse aqui é ressaltar alguns pontos emblemáticos dos saltos qualitativos ocorridos em Matemática, levando a novas direções de abstração criativa. Novas ideias representam aberturas conceituais, que surgem em determinadas circunstâncias, muitas vezes casuais, e que podem ou não ser aceitas pela cultura onde surgiram.

A matemática grega teve um pico em Alexandria mas depois teve um declínio devido a fatores políticos no Egito e em todo o Mediterrâneo, e também o início de preocupações espirituais com o cristianismo. Vale a pena mencionar a primeira mulher a distinguir-se em matemática, filosofia e medicina, em Alexandria, Hypatia $(370$ - 415), da escola neo-platônica, mística, mas oposta ao cristianismo.

Roma começou a se expandir para fora da Itália, conquistando a Grécia em 146 a.C., e também a Ásia Menor e a Mesopotâmia. A Pax Romana trouxe estabilidade política, mas os romanos tinham interesses práticos, de engenharia, não se interessavam nem pela filosofia nem pela matemática gregas antigas.

Depois de 330 d.C. o império romano se divide numa parte oriental, centrada em Constantinopla, e numa parte ocidental, que é invadida e conquistada pelos povos bárbaros. Como resultado das conquistas árabes na península ibérica, três civilizações contrastantes surgiram no Mediterrâneo: a bizantina, a Europeia latina, e a islâmica, herdeiras do antigo império romano. Os textos em grego foram depois traduzidos arduamente para o árabe, muito depois para o latim, retornando à Europa muitos séculos depois.

Na Europa, no período das invasões bárbaras, século 5, até o século 11, não houve desenvolvimento da matemática, e nada sobrou das civilizações antigas, a Igreja católica tornou-se a única guardiã da vida intelectual, preservada nos mosteiros, como única instituição nas ruínas romanas.

Durante o século 9 o rei Carlos Magno deu alguma importância à educação, e foi restaurado nos monastérios o ensino das artes liberais, como existiram na Grécia, com o quadrivium (aritmética, geometria, astronomia e música) e o trivium (gramática, retórica e lógica). Muitos manuscritos foram traduzidos e a cidade de Aachen (Aix La Chapelle em francês) tornou-se um centro de cultura, dita "pequena renascença", mas matemática não era uma necessidade nessa sociedade. Novas invasões levaram à destruição do império, originando as nações separadas da França, Alemanha e Itália. As cruzadas no período 1095-1291, conhecidas na época como "peregrinação" e "guerra santa", originaram-se em sua maioria nos territórios do antigo Império Carolíngio.

O primeiro grande matemático europeu da Idade Média foi Leonardo Fibonacci, italiano de Pisa $(1170$ - 1250), que escreveu a primeira obra importante sobre matemática desde os gregos, o Liber Abaci, introduzindo os numerais hindu-arábicos na Europa, além de discutir muitos problemas matemáticos. Com seu pai, Guglielmo dei Bonacci, representante dos comerciantes da República de Pisa na Argélia, Fibonacci ainda muito jovem teve contato com o mundo do comércio e aprendeu técnicas matemáticas desconhecidas no Ocidente, difundidas pelos estudiosos muçulmanos. Alguns desses procedimentos haviam sido criados por matemáticos da Índia, uma cultura muito distante da mediterrânea. Percebendo que a aritmética, com algarismos arábicos, era mais simples e eficiente do que com os algarismos romanos, Fibonacci viajou por todo o mundo mediterrâneo, chegando até Constantinopla, para estudar com os matemáticos árabes mais importantes, alternando os estudos com a atividade comercial. O ponto mais importante do sistema desenvolvido na Índia correspondia ao algarismo ZERO para compor a sequência de números, permitindo o sistema posicional para adição e subtração de números. A descoberta do zero, ou espaço vazio, é um passo conceitual essencial, que marca o nível de desenvolvimento de uma cultura. Não existia na Grécia, cuja filosofia não aceitava a existência do vazio, e não 
existia nos algarismos romanos, mas existia no sistema de cordas e nós dos Incas do Peru, onde uma posição vazia pode ser detectada em cordas adjacentes.

O legado de Fibonacci passou aos mosteiros europeus, sem repercussão imediata. Novo avanço demorou muito, mas o crescimento das universidades nos séculos 12 e 13 foi uma consequência natural da demanda que os monastérios não podiam mais satisfazer. Universitas eram corporações medievais de estudantes e mestres, que depois tiveram reconhecimento de autoridades civis e religiosas, dando origem às Universidades de Bolonha (1088) e Paris (1150), as primeiras, que serviram de modelo às outras, Pádua (1222), Oxford (1214) e Cambridge (1231). Inicialmente sem prédios próprios, as aulas eram na residência dos mestres, depois a competição por bons mestres levou a salários pagos pela municipalidade.

As universidades medievais eram centros de saber, alem das Artes Liberais preparatórias ensinavam leis, medicina e teologia. Em Bolonha dominava a jurisprudência, enquanto em Paris dominavam estudos religiosos, Montpellier fundada em 1289 ficou conhecida pela Medicina. Em Oxford dominavam as matérias cientificas do quadrivium, enquanto França e Itália tinham predomínio do trivio.

No século 14 a situação na Europa regrediu de forma acentuada, com fome, pragas, guerras, inundações e mortes. Mas por volta de 1450 as calamidades passaram, um novo período de prosperidade começa, as cidades e as populações crescem. Dois séculos de caos e revoluções levaram os povos a preferir a estabilidade de novas monarquias reais, de Luis XI na França (1461), Fernando e Isabel na Espanha (1477) e Henrique VII na Inglaterra (1485), marcando a morte do feudalismo.

Ao mesmo tempo ocorrem eventos marcantes: a queda de Constantinopla para os turcos otomanos (1453) levou os intelectuais a se refugiarem na Europa, levando consigo os manuscritos clássicos em grego para a Europa. A invenção da prensa com tipos móveis por Johannes Gutenberg (1450) marca mudanças profundas na Alemanha, com tradução da Bíblia para o alemão. As grandes navegações, com descoberta da América patrocinada pelos reis católicos da Espanha (1492), e a expulsão dos árabes da Espanha no mesmo ano, mudaram o mundo.

O período de transição entre meados do século XIV e o fim do século XVI é conhecido como Renascença, com características diferentes no norte da Europa e na Itália. No início da impressão de livros houve muito pouco interesse em Matemática, dominavam a Bíblia, textos religiosos, e calendários, e alguns textos de interesse comercial, com início do uso de algarismos arábicos substituindo os algarismos romanos. A reforma protestante sacudiu a Alemanha, com o monge Martinho Lutero publicando suas 95 teses em 31 de outubro de 1517, na porta da igreja do castelo de Wittenberg, com críticas à venda de indulgências e aos abusos do clero católico, pregando um retorno às Escrituras Sagradas. O movimento estendeu-se a vários países europeus, e a Igreja Católica reagiu com a Contra-Reforma, a fundação da Companhia de Jesus em Paris, liderada pelo basco Inacio de Loyola, e o Concilio de Trento (1545 - 1563). Guerras religiosas entre católicos e protestantes dividiram a Europa no período 1618-1648. Na Itália os estudiosos desenvolveram uma devoção ao estudo dos textos clássicos, e isso deu características diferentes à renascença italiana. É nesse ambiente de litígio que no século 16 avançam os conhecimentos de Física e Astronomia descritos nos itens anteriores, envolvendo também a Matemática.

Nesse período merece destaque Renée Descartes (1596 - 1650), filósofo, físico e matemático francês, que além da frase célebre "Cogito, ergo Sum", desenvolveu as coordenadas cartesianas fundindo a Álgebra com a Geometria.

O século 17 viu surgir a Matemática moderna, junto com as mudanças políticas, econômicas e sociais da Renascença. A partir de um início empírico muito antigo, ligado aos jogos de 
azar e à necessidade de dados estatísticos para cálculos de seguro, a teoria matemática de probabilidade teve início na correspondência entre os matemáticos franceses Pierre de Fermat (1601 - 1665) e Blaise Pascal (1623 - 1662), que além de matemático era também literato e com preocupações religiosas.

Outra direção de interesse geral é a Música, que existe também desde os primórdios da Humanidade, com estreita ligação com Matemática. É bem conhecido o fato de Pitágoras ter estabelecido as escalas musicais harmônicas, a partir de estudos com o monocórdio, uma corda tensionada por um peso, produzindo sons ao vibrar. A harmonia depende da relação entre a corda tocada solta (tônica) e as outras notas obtidas pressionando o monocórdio em frações simples do comprimento da corda. A nota obtida ao tocar a corda na metade do seu comprimento é interpretada pelo ouvido humano como sendo a mesma nota. Para melhor compreensão da matemática envolvida muita informação pode ser obtida na internet, cito um bom texto. ${ }^{12}$ Foram inicialmente definidas 4 notas no monocórdio, nas razões 1 (Tonica) 1/2 (oitava) 2/3 (quinta) 3/4 (quarta) do comprimento da corda. Diz a lenda que Pitágoras percebeu a harmonia ao ouvir sons das batidas de martelos numa oficina de ferreiro, e que os martelos que produziam os sons melhores pesavam 12, 9, 8 e 6 unidades de massa, ou seja, nas razões harmônicas, tomando-se 12 como unidade. Outras escalas foram usadas na Grécia, e também em outras culturas humanas.

A notação musical ocidental atual teve origem nos símbolos usados para pontuar os cantos gregorianos, por volta do século 8. Esse sistema evoluiu até uma pauta de quatro linhas, com claves que permitiam representar a tonalidade, que define a extensão das notas na pauta, que varia com o instrumento musical utilizado. O desenvolvimento da notação absoluta das alturas das 7 notas e sua duração foi feita na Idade Média pelo monge beneditino Guido d'Arezzo (992 - 1050), sendo a oitava a nota harmônica da primeira. Idealizou o solfejo, ensino musical que permite o canto das notas, nomeadas a partir da primeira silaba de um hino a São João Batista.

Nas universidades medievais da Europa, a Música era estudada junto com a Matemática, o conhecimento musical estava nos mosteiros e a música assumiu uma importância muito grande, na realização das liturgias nas Igrejas e nas manifestações populares. Na Renascença italiana a música sacra era cantada, uma extensão do canto gregoriano medieval, que dependia da Igreja e de reis, mas havia também música laica, mais instrumental, por músicos diletantes ou profissionais. Depois de 1470 a produção musical laica era impressa em pequenos livros, enquanto igrejas e monastérios preferiam manuscritos. Na segunda metade do século 16, na Itália, principalmente em Veneza, a execução simultânea de diversos coros e conjuntos de instrumentos nas naves das Igrejas, faz surgir a polifonia, e música vocal secular, sem uma teoria explicativa. Nesse contexto foi marcante a presença de Vincenzo Galilei (pai de Galileu), músico teórico e prático, alaudista e compositor, professor independente, que editou e traduziu teóricos de música da Grécia, e fez parte do grupo Camerata Fiorentina. Divergia do conceito pitagórico de música como número, enfatizando a experiência perceptiva real do som, mas como Ciência. Seus escritos tiveram repercussão recente, ${ }^{13}$ que mostram sua importância em estudos da Física do som, fez experiências com vários instrumentos e vários materiais, contribuído à noção de timbre musical.

O desenvolvimento seguinte está ligado à invenção dos Logaritmos pelo barão escocês John Napier (1550-1617), de grande utilidade prática em cálculos, e o desenvolvimento da escala temperada em música por Johann Sebastian Bach (1685 - 1750). Os intervalos entre as freqûencias sonoras das 7 notas não era sempre o mesmo, o que dificultava a transposição de melodias,

\footnotetext{
12 do Carmo Pereira, Marcos. Matemática e Música De Pitágoras aos dias de hoje. Rio de Janeiro: TCC Mestrado, Universidade Federal do Estado do Rio de Janeiro, Centro de Ciências Exatas e Tecnologia, Curso de Pós-graduação em Matemática, 2013.

${ }^{13}$ Bromberg, 2011, op. cit.
} 
e essa pequena diferença entre alguns intervalos foi objeto de estudo por parte de músicos do ocidente por séculos.

A solução encontrada para corrigir esse problema foi o temperamento da escala, isto é, a divisão equânime dos intervalos para que eles pudessem estar a uma mesma distância entre si. Várias formas de temperamento foram usadas, mas atualmente na mais adotada as sete notas da escala se tornam doze, com a inclusão de cinco notas colocadas propositalmente entre algumas das sete. Esse temperamento foi proposto em 1691, por Andreas Werckmeister e utilizado com maestria por J. S. Bach em O Cravo Bem-Temperado, uma obra de caráter didático composta em dois volumes na qual o músico faz um passeio por todos os doze semitons da nova escala. Toda a sua obra, e essa em especial, influenciou músicos do mundo inteiro e mudou o paradigma vigente. No piano as teclas pretas representam as 5 notas incluídas entre as 7 teclas brancas, com mesmo intervalo em frequência entre todas elas. Para que se possa entender essa relação, devese pensar na escala musical como uma escala logarítmica.

A matemática exata, que lida com um mundo ideal, se modificou ao longo do século 17, ultrapassando a separação entre estudos nas universidades e fora dela, como por exemplo Niccolò Tartaglia na Itália. Essa mudança está ligada ao início do cálculo infinitesimal, em problemas práticos, e esse processo envolvendo lutas políticas, intelectuais e religiosas está descrito em livro de grande repercussão, recentemente traduzido para o português. ${ }^{14} \mathrm{O}$ desenvolvimento científico se desloca para o eixo definido pelo canal da Mancha, com avanço maior no norte da Europa.

Os avanços a partir do século 18 levaram a Matemática a um patamar de abstração inacessível a leigos, e aqui o interesse está focalizado nas mudanças conceituais de interesse geral. Creio poder afirmar que existe uma evolução dialética entre aplicações práticas da matemática e seu aspecto rigoroso, que leva a altas abstrações, mas que só adquirem interesse amplo quando surge alguma aplicação, seja em física teórica seja no mundo real.

\section{A União da Física com a Química}

A Física como ciência começa com Galileu, no Renascimento, mas o início da Química como ciência é bem mais recente. A chamada "Física Clássica" se definiu, a partir de Newton, com grande desenvolvimento nos séculos 18 e 19, englobando Mecânica, Óptica, Termologia, Eletricidade e Magnetismo. Só durante o século 17, a alquimia começou a evoluir na direção da Química Moderna a partir dos estudos de alquimia populares entre muitos dos cientistas da época. A História da Química pode ser acessada em vários sites e na Wikipédia, com muitos links que permitem uma visão bastante abrangente. Menciono apenas alguns tópicos, que unem interesse histórico com conteúdo científico, conforme livro recente, ${ }^{15} \mathrm{em}$ que se buscou também um mecanismo de transferência dos conhecimentos de fronteira à sociedade.

A Química, englobando todas as transformações de matérias e suas explicações, existe desde os primórdios da humanidade, e a alquimia nasceu em Alexandria por volta do século 9

\footnotetext{
${ }^{14}$ Alexander, Amir. Infinitesimal, A teoria matemática que revolucionou o mundo. Tradução George Schlesinger. $1^{\mathrm{a}}$ edição. Rio de Janeiro: Zahar, 2016. Primeira edição americana, Nova York: Scientific American / Farrar, Straus and Giroux, 2014.

15 Queiroz do Amaral, Lia. Introdução: do modelo atômico aos materiais do cotidiano, capitulo I, pp. 19-28. In Queiroz do Amaral, Lia (organizadora). Entre sólidos e líquidos. Uma visão contemporânea e multidisciplinar. Para formação de professores e divulgação do conhecimento. São Paulo: Editora Livraria da Física, 2014. Este item do artigo reproduz ideias e mesmo alguns parágrafos do autor, com autorização da Editora Livraria da Física.
} 
a.C. Os alquimistas tentavam conseguir ouro a partir de diversos metais. Seu objetivo era a fabricação da pedra filosofal, que transmuta os metais em ouro e permite a preparação do elixir da panaceia ou remédio universal.

O nobre irlandês Robert Boyle (1627-1691), inicialmente ainda alquimista, é considerado um dos pais do método científico na Química com seu livro The Sceptical Chymist (1661), onde enfatiza não existirem apenas os 4 elementos aristotélicos (terra, água, ar e fogo) e valoriza a experimentação, mostrando como empregar padrões de termos e nomenclaturas nas explicações e apresentações de novos compostos químicos. Fez várias pesquisas sobre o comportamento elástico do ar. Demonstrou a existência da pressão atmosférica e a lei que leva seu nome, sobre a relação inversamente proporcional entre a pressão e o volume do ar contido num recipiente a temperatura constante. Ele também defendeu que a química não deveria somente servir a medicina e a alquimia, mas ascender à condição de ciência, e foi um dos fundadores da Royal Society. Newton foi influenciado Boyle, 15 anos mais velho que ele; as relações entre ambos foram evidenciadas numa longa carta escrita por Newton a Boyle em 1678/9, em que discute o éter, com menções alquímicas. Essa carta foi localizada e publicada pelo Newton Papers Project na internet, em fevereiro de 2013.

As palavras "alquimia" e "química" foram usadas indistintamente no século 17, mas no século 18 definiu-se uma distinção rígida entre as duas, com o trabalho quantitativo do francês Antoine Laurent de Lavoisier (1743-1794), pai da Química Moderna, que deu passos essenciais para a descoberta do oxigênio (completando as descobertas independentes do químico farmacêutico sueco Carl Wilhelm Scheele e do teólogo e filosofo natural britânico Joseph Priestley), a lei da conservação da massa e a teoria da combustão. Lavoisier morreu guilhotinado na revolução francesa, em parte devido ao ódio que Jean Paul Marat, um dos líderes da Revolução Francesa nutria por ele, pois Marat candidatou-se a uma vaga na Academia, em 1780, e foi recusado por defender a teoria equivocada do flogisto, sobre a combustão, que Lavoisier havia elucidado. A estruturação da notação atual das fórmulas químicas foi obra do químico sueco Jöns Jacob Berzelius (1779 - 1848), que adotou as ideias de Lavoisier.

Aqui focalizo a união da Física com a Química, que ocorreu na passagem do século 19 para o século 20, e formou o que hoje chamamos de "Ciências Exatas". Para mostrar a unificação da Física com a Química numa perspectiva histórica, uma abordagem não muito explorada na Física é a história do número de Avogadro, $\mathrm{N}_{\mathrm{A}}$, mais conhecido em Química. A definição tanto conceitual quanto histórica de $\mathrm{N}_{\mathrm{A}}$ é um bom exemplo dessa unificação, pois serve como ligação entre várias constantes físicas e corresponde a um fator de escala quando se passa da escala atômica para a escala macroscópica. É uma constante física fundamental, tendo relação matemática com a constante de Planck da Mecânica Quântica e importância direta para vários campos da ciência e da tecnologia.

A ideia do modelo atômico foi retomada da Grécia antiga pelo cientista britânico John Dalton (1766 - 1844), que após estudos de misturas de gases, desenvolveu sua teoria atômica numa série de conferências que proferiu entre 1804 e 1805 na Royal Institution de Londres, fundada em 1799. Considerou o hidrogênio, o elemento mais leve, como unidade, elaborando a primeira tabela de pesos atômicos. Dalton representava o átomo com formato redondo, tipo bola de bilhar, e sua teoria atômica não conseguia explicar vários compostos moleculares, ou seja, não havia ainda uma diferença clara entre átomos e moléculas, definidas qualitativamente como a menor porção de uma substância que ainda retém suas propriedades físicas e químicas.

A distinção entre átomos e moléculas foi feita por Lorenzo Romano Amedeo Carlo Avogadro, conde di Quaregna e di Cerreto (Turim, 1776-1856), advogado e físico italiano, autor de um dos mais importantes princípios da química moderna, a hipótese conhecida como lei de Avogadro. Apesar de formado em ciências jurídicas e de haver praticado a advocacia por alguns anos, Avogadro manifestou, desde cedo, interesse pela química. Em 1809 foi admitido como professor 
de física no Reale Collegio di Vercelli e depois obteve a cadeira de física da Universidade de Turim. Em 1811 enunciou sua famosa hipótese: “o número total de moléculas em qualquer gás é sempre o mesmo para volumes iguais, ou seja, é sempre proporcional aos volumes”.

A hipótese de Avogadro foi retomada por Stanislao Cannizzaro (1816-1910), químico italiano que participou do Risorgimento (movimento pela unificação da Itália), exerceu atividade política como senador e foi professor da Universidade de Genova. Em 1858 Cannizzaro esclareceu a hipótese de Avogadro e precisou a distinção entre peso atômico e peso molecular, consagrando a hipótese de Avogadro como lei. Peso Atômico (ou massa atômica relativa) de um elemento foi definido como o número de vezes que um átomo daquele elemento é mais pesado que um átomo de hidrogênio, considerado como a unidade. O peso molecular corresponde ao peso total do conjunto de átomos de uma molécula.

Em 1860 foi realizada em Karlsruhe, na Alemanha, a primeira conferência internacional de Química, para unificar a notação, nomenclatura e pesos atômicos das substâncias. Nela, as ideias de Avogadro e Cannizzaro foram reconhecidas e a teoria atômica da matéria foi estabelecida definitivamente. Mas Avogadro e Canizzarro nunca tentaram medir a densidade numérica de moléculas, ou o número de moléculas em um dado volume, e grandes físicos positivistas do século 19 consideravam átomos como uma construção matemática conveniente, sem realidade física. Em particular lord Kelvin (William Thomson), físico-matemático e engenheiro irlandês que criou a escala absoluta Kelvin de temperatura, deu contribuição importante ao conceito de entropia, na termodinâmica. Mas calculou a idade da Terra admitindo que houve resfriamento a partir da temperatura inicial igual à do Sol, chegando num valor muito pequeno, incompatível com as descobertas de fosseis, e morreu sem aceitar as ideias que revolucionaram a Física.

Em 1869 Mendelejev apresenta a tabela periódica dos elementos, sistematizando as propriedades dos elementos químicos até então conhecidos e foi prevista a existência de seis novos elementos, depois descobertos. Essa tabela simboliza o nascimento da Química como ciência, sua explicação só se tornou possível após a união da Física com a Química.

Valores numéricos de $\mathrm{N}_{\mathrm{A}}$ só puderam ser obtidos pelo físico austríaco Johann Josef Loschmidt em 1865 usando a teoria cinética dos gases. Os primórdios dessa teoria são mais antigos, mas dificuldades conceituais impediram seu desenvolvimento, e só renasce com o trabalho do físico alemão Rudolf Clausius (1822-1888). A introdução do conceito de caminho livre médio das partículas, entre choques sucessivos, permitiu dar um tratamento matemático ao fenômeno da condução de calor em gases. Em seguida, o físico escocês James Clerk Maxwell (1831-1879) desenvolve a ideia de uma distribuição estatística de velocidades das moléculas, detalhada pelo físico austríaco Ludwig Eduard Boltzmann (1844 - 1906), fundando as bases da mecânica estatística.

Loschmidt, que foi mentor de Boltzman na escola vienense de termodinâmica, deduziu o tamanho das moléculas no ar, a partir do caminho livre médio das moléculas, usando uma proporção: o volume de um gás está para o volume de todas as moléculas nele contidas, assim como o caminho livre médio de uma molécula está para 1/8 do diâmetro da molécula. O método foi descrito alguns anos depois por Maxwell, num artigo da Nature, ${ }^{16}$ onde chega ao número de partículas de um gás por unidade de volume, que recebeu o nome de constante de Loschmidt ${ }^{17}$.

O modelo atômico desenvolvido na virada do século 19 para o século 20 pela Física Moderna se concentrou em explicar o átomo de hidrogênio em detalhe, e não vamos repetir aqui as etapas desse processo, que pode ser encontrado em inúmeros outros textos, tanto de História como de Física.

${ }^{16}$ Maxwell, James Clerk. Molecules. Nature v. 8, n. 204, p. 437-41, 1873

${ }^{17}$ Virgo, S. E. Loschmidt' s Number. Science Progress v. 27, p. 634-649, 1933. 
A existência dos átomos e moléculas só foi aceita de forma inconteste com a observação em microscópios do movimento browniano aleatório, devido aos choques de partículas visíveis com moléculas invisíveis. O segundo trabalho do físico alemão Albert Einstein, no ano memorável de 1905, foi sobre o movimento browniano, relacionando as grandezas estatísticas desse movimento com o comportamento dos átomos. Isso possibilitou o trabalho experimental do francês Jean-Baptiste Perrin, de 1908 (trabalho publicado em francês em 1909 e depois traduzido para o inglês), considerado a prova final da existência de átomos e moléculas, pelo qual recebeu o prêmio Nobel de Física em 1926, ${ }^{18}$ e foi dele a atribuição do nome "número de Avogadro", então já falecido. O Volume de Avogadro é o volume ocupado pelo número de moléculas $\mathrm{N}_{\mathrm{A}}$ no gás ideal, obtido por rearranjo da equação de estado do gás ideal, seu valor é 22,4 litros a $0^{\circ} \mathrm{C}$ e 1 atmosfera de pressão.

Para sólidos e líquidos não se pode falar em um "volume de Avogadro", mas o número de Avogadro define um conjunto de partículas, denominada "mol", e essa quantidade de partículas está associada à massa molar (em unidades atômicas de massa). O termo mol foi introduzido na Alemanha em 1893, e logo depois levado para o inglês. Massa molar é a massa de substância que contém $6,02 \times 10^{23}$ entidades representadas pela fórmula química dessa substância. É um número tão grande que exige notação científica, em potências de dez, e é comumente expressa em $\mathrm{g} / \mathrm{mol}$ ou $\mathrm{g} \mathrm{x} \mathrm{mol}^{-1}$. Ambas as palavras mol e moléculas têm sua origem no latim mole, significando porção, quantidade, grande massa.

Inicialmente, a Química considerou a massa do átomo de hidrogênio como unidade atômica de massa. Porém, a descoberta de isótopos de uma mesma substância química, mas com número de nêutrons diferente, criou um problema na atribuição do peso atômico. O mol passou a ser a unidade de base para a grandeza quantidade de matéria ou quantidade de substância do Sistema Internacional de Unidades (SI), estabelecido em 1959-1960. Físicos e químicos fizeram um acordo histórico em 1961, passando a usar o isótopo Carbono-12 como base de unidade de massa. O número de Avogadro, adimensional, passou a ser definido como o número de átomos em $12 \mathrm{~g}$ de C-12. Em 1971 o mol passou a integrar o SI e as definições foram trocadas. O mol foi definido como o número de átomos em $12 \mathrm{~g}$ de C-12, com a dimensão de "quantidade de substância", e o número de Avogadro tornou-se uma constante física, com unidade "por mol" (ou mol-1). A troca foi feita em função de definir quais são "constantes fundamentais" e quais são grandezas derivadas.

Apesar de ser um número imenso de partículas, um mol de uma substância pode se referir a um volume pequeno. Um mol de gás nitrogênio $\left(\mathrm{N}_{2}\right)$ inflará um balão com um diâmetro de $30 \mathrm{~cm}$. Mas $1 \mathrm{~mol}$ de água líquida ocupa um volume um pouco maior que uma colher de sopa cheia $(18 \mathrm{~mL})$. Um mol de açúcar de cana (sacarose $\left.-\mathrm{C}_{12} \mathrm{H}_{22} \mathrm{O}_{11}\right)$ tem $342 \mathrm{~g}$. Todas estas quantidades de substâncias citadas estão contidas em um mol, apresentando 6,02 × $10^{23}$ moléculas. Esse volume pequeno do mol é devido ao valor típico das distâncias entre partículas nos estados líquido e sólido. A distância entre átomos, como demonstrado pela difração de raios-X no início do século 20, é tipicamente da ordem de 1 Angstrom $=10^{-8} \mathrm{~cm}$, ou de 0,1 nanometros $(\mathrm{nm}=$ $10^{-9} \mathrm{~m}$ ). Assim, 1 mol ocupa, no estado gasoso, 22,4 litros, porém dezenas ou centenas de mililitros na matéria condensada, ou seja, existe um fator entre 100 e 1000 de diferença na densidade de partículas na passagem do estado gasoso para o estado que chamamos "matéria condensada", englobando líquidos, sólidos e estados intermediários.

A unidade mol é uma grandeza adimensional (sem unidades), utilizada para descrever uma quantidade (assim como a "dúzia") correspondente ao número de Avogadro. Porém, o uso do mol mostra-se adequado somente para descrever quantidades de entidades elementares.

${ }^{18}$ Palestra proferida por Jean Baptiste Perrin ao receber o prêmio Nobel: http://www.nobelprize.org/nobel_prizes/physics/laureates/1926/perrin-lecture.html?pri 
Quando o mol é usado para especificar a quantidade de uma substância, é necessário identificar o tipo de entidade elementar da substância, que pode ser átomos, moléculas, íons, fórmulas químicas (por exemplo $\mathrm{Na}^{+} \mathrm{Cl}^{-}$), elétrons, fótons, outras partículas ou grupos específicos de tais partículas. Por exemplo, um mol de água é equivalente a 18,016 g de água, e contém um mol de moléculas $\mathrm{H}_{2} \mathrm{O}$ : dois moles de $\mathrm{H}$ e um mol de $\mathrm{O}$. A carga de um mol de elétrons é dada pela constante de Faraday, um mol de fótons é chamado um Einstein, etc.

A Física passou, depois, a buscar a compreensão aprofundada do comportamento dos núcleos, e suas partículas elementares. Elétrons foram sempre de interesse tanto da Física como da Química. A compreensão da estrutura do átomo de hidrogênio permitiu, por sua vez, a explicação da tabela periódica dos elementos químicos, que havia sido definida de forma empírica. Os vários elementos químicos puderam ser entendidos pelas diferenças no preenchimento das camadas eletrônicas. A posição de um elemento nessa tabela é definida pelo número de prótons do núcleo, chamado número atômico. A Química estuda as moléculas formadas pela união estável de vários átomos, e as reações que ocorrem entre elas, relacionadas à troca e compartilhamento de elétrons de ligação entre átomos, formando diferentes moléculas. Essas duas ciências exatas se complementam e se superpõem na explicação da matéria, e pesquisas interdisciplinares se tornam cada vez mais frequentes e necessárias.

A constante de Avogadro pode ser considerada emblemática da união da Química com a Física. A história do número de Avogadro e do mol ilustra bem a lógica do processo científico, em que as contribuições de cientistas de vários países se encadeiam ao longo do tempo, construindo aos poucos o conhecimento em profundidade. Os conteúdos, impessoais, são depois racionalizados, o que pode inverter as definições e muitas vezes até o processo histórico. Hoje em dia, a visão microscópica tornou-se usual, com sistema de medidas muito bem definido e usado universalmente. É interessante também ressaltar que a fundação da IUPAC (International Union of Pure and Applied Chemistry) data de 1919, num processo que começou com a Primeira Conferência Internacional de Química em 1860. Já a IUPAP (International Union of Pure and Applied Physics) foi fundada em 1922, e sua primeira Assembleia Geral ocorreu em Paris em 1923.

O que interessa ressaltar é que existe uma "lógica interna" no conteúdo científico das Ciências Exatas, é mais uma 'descoberta' do mundo externo ao ser humano, do que uma invenção humana. O conhecimento científico adquirido no ultimo século tem capacidade pratica de agir sobre o mundo e altera-lo. As questões filosóficas passam a ser de caráter ético, focalizadas no ser humano e sua atuação sobre a Natureza.

\section{Metodologia científica e interdisciplinaridade}

Faço menção agora a um livro que discute o Método Científico, com um enfoque Histórico e Filosófico, ${ }^{19}$ analisando em detalhe a dedução lógica, a partir de hipóteses definidas, e a inferência indutiva, a partir de fatos observados, bem como o papel da estatística no método científico. Mas não existe uma conclusão clara.

Observação, modelos, teorias e experimentos são essenciais no avanço do conhecimento humano, mas a forma de entrelaçamento entre esses fatores não é nada trivial, nem é possível

\footnotetext{
${ }^{19}$ Gower, Barry. Scientific Method. An historical and philosophical introduction. First published 1997, by Routledge. This edition published in the Taylor \& Francis e-Library, 2002. Simultaneously published in the USA and Canada by Routledge
} 
definir facilmente o que é necessário para esse avanço ocorrer. Percepções e ideias nascem na mente de indivíduos e precisam ser expressas para se tornarem efetivas numa sociedade.

Um artigo recente escrito para público leigo descreve a forma de validação da produção científica, ${ }^{20}$ analisando as origens históricas do processo de avaliação por pares vigente, e também as modificações surgidas na última década, com alterações radicais na forma de transmissão do conteúdo científico.

É essencial enfatizar a necessidade do debate de ideias na evolução da Ciência. Na Renascença tornou-se comum que intelectuais trocassem cartas num debate livre de ideias, e dezenas de sociedades foram formadas na Europa a partir do século 14, inicialmente reunindo literatos e pintores. A primeira sociedade científica foi a Academie des Lynces (Roma, 1603), patrocinada pelo príncipe Federico Cesi, e Galileu Galilei foi um de seus membros. Deu origem à Pontifícia Academia de Ciências, que até hoje promove a pesquisa e examina questões científicas de interesse da Igreja.

A sociedade científica laica mais antiga que existe até hoje é The Royal Society of London for the Improvement of Natural Knowledge, fundada em 1660 por filósofos naturais e médicos, logo apoiada pelo rei Charles II. Um pouco depois surge a Académie des Sciences (Paris 1666), fundada por Luís XIV por sugestão do ministro Jean-Baptiste Colbert, e atualmente integrada ao Institut de France. As sociedades inglesa e francesa tinham filosofias diferentes desde seu início. O lema da Royal Society Nullius in Verba (Nas palavras de ninguém), é o símbolo da liberdade de expressão e comprovação através de experiências.

Hoje em dia o grau de especialização é tão grande que o diálogo entre os vários ramos da ciência é quase inexistente. Mas por outro lado, o interesse em adquirir conhecimento tem levado a propostas originais de Divulgação Científica, para público amplo. Um bom exemplo é o livro que vendeu milhões de exemplares, ${ }^{21}$ de um jornalista que se dispôs a retomar o interesse que havia tido na infância em ciência, mas da qual se afastou porque os textos da escola não respondiam suas perguntas. Esse livro foi utilizado no curso de Iniciação ao Pensamento Científico, para introduzir conceitos básicos sobre o início da Geologia, e estudos sobre a Terra, que não são tratados nos cursos de Física. Esses estudos, com participação amadorística de nobres ingleses no século 18, foram responsáveis no século 19 por uma revolução no conhecimento, tanto pela descoberta de fosseis cuja antiguidade permitiu conhecer a idade da Terra como pela descoberta da deriva dos continentes. O livro entra também em questões relativas à Vida na Terra, de forma a mesclar jornalismo com Divulgação Científica, num tratamento que visa unir Conhecimento e Ciência, mas sem os rigores da Academia.

No último semestre do referido curso para Terceira Idade, foram abordados vários usos práticos de tecnologia moderna, a partir de perguntas dos alunos, visando fornecer explicações que estivessem ao alcance de seu entendimento, sem excesso de detalhamento teórico.

A experiência de 3 semestres com adultos de Terceira Idade, somada à experiência com alunos e professores de Ensino Médio, me mostrou que a forma de ensinar Ciência necessita mudança profunda, focalizando conceitos básicos de alfabetização científica. Detalhamento exato só interessa num grau de especialização posterior, para os que tiverem interesse real num determinado assunto.

\footnotetext{
${ }^{20}$ Queiroz do Amaral, Lia. O processo de validação do conhecimento científico. Jornal da USP, 24/04/2017..

${ }^{21}$ Bryson, Bill. Breve história de quase tudo, Do big-bang ao Homo Sapiens. Tradução Ivo Korytowski. São Paulo: Companhia das Letras, 2005.
} 
Quanto às questões sociais envolvidas, é conveniente ressaltar a importância do conhecimento prático, que sempre existiu fora das universidades. Ofícios na Idade Média eram executados por artesões que dominavam o "saber fazer" e as corporações dos construtores e dos Artesãos surgidas a partir do século 12 tinham hierarquias definidas (mestres, oficiais e aprendizes), ligadas à produção e ao comércio, que deram origem às estruturas sociais posteriores à Revolução Industrial. A Revolução Científica pode ser vista como um prelúdio à Revolução Industrial, com avanços no conhecimento básico, levando depois a mudanças tecnológicas e sociais.

É necessário ainda ressaltar que a forma de tratar conteúdos das Ciências Exatas difere da forma de tratar conteúdos das Ciências da Vida, pois ambas partem de bases conceituais diferentes. O desenvolvimento da Biologia Molecular a partir da segunda metade do século 20 levou a muitos avanços em áreas especificas, na interface com Química e Física, mas esse conhecimento exato ainda não consegue equacionar a funcionamento da mais simples célula viva. A complexidade da vida ainda não foi desvendada.

Existe certamente o ideal das ciências exatas e as ciências da vida se unirem como Ciências da Natureza, mas isso ainda exige muito esforço de pesquisa interdisciplinar, para construção de pontes entre áreas disjuntas. Um exemplo nessa direção é um livro recente ${ }^{22}$ que volta à proposta original de Darwin sobre seleção sexual, para explicar a evolução da beleza e a questão do acasalamento, ainda não explicado pela Ciência. Em Medicina os avanços científicos são imensos, mas continua sendo uma ciência empírica, e mesmo as técnicas mais desenvolvidas dependem das percepções humanas para sua compreensão e interpretação correta.

Os desafios do mundo atual exigem novas abordagens, que ainda não se definiram, mas que passam por uma integração do ser humano com o universo que o rodeia. Creio poder afirmar que existe no nível de cada indivíduo uma infraestrutura material, e uma superestrutura mental, de ideias e conceitos, que permite o controle de processos e técnicas operacionais, que definem sua existência concreta.

O desenvolvimento da Física e da Química exatas permite o conhecimento da Matéria e suas interações básicas no nível atômico e molecular, que está levando tanto à compreensão dos materiais naturais como à possibilidade de materiais artificiais com propriedades próximas das biológicas. O desenvolvimento da Matemática aplicada a Computadores levou ao surgimento da Realidade Virtual. De certa forma estamos de volta ao cruzamento das concepções gregas sobre a physis da Natureza e do Cosmo, que dominaram a cultura ocidental, já existe uma síntese entre Demócritus, Platão e Aristóteles. Parece ter chegado a hora de uma síntese com as culturas milenares do Oriente.

22 Prum, Richar O. The Evolution of Beauty. How Darwin's Forgotten Theory of Mater Choice Shapes The Animal World and Us. New York: Doubleday, 2017. 